\title{
Developing students' intercultural communicative competence through cultural text-based teaching
}

\author{
Indah Permatasari and Erna Andriyanti* \\ English Education Department, Faculty of Languages and Arts, Universitas Negeri Yogyakarta, Kampus \\ Karangmalang, Yogyakarta 55281, Indonesia
}

\begin{tabular}{|c|c|}
\hline \multicolumn{2}{|c|}{$\begin{array}{l}\text { ABSTRACT } \\
\text { Teaching a foreign language needs to include its relevant culture as the context of the } \\
\text { language use. However, studies indicate that many English lecturers in Indonesia have not } \\
\text { integrated culture yet in their teaching materials, resulting in students' low intercultural } \\
\text { communicative competence (ICC). This three-cycle class action research was aimed to improve } \\
\text { the ICC of first semester students majoring in metallurgy engineering through cultural text- } \\
\text { based intercultural teaching. It was designed to overcome problems related to the limited } \\
\text { opportunity for speaking practice and insufficient cultural contents in the English materials. } \\
\text { Classroom observations and interviews with } 22 \text { students and the lecturer revealed that this } \\
\text { cultural text-based intercultural teaching was practical to improve the students' ICC. The } \\
\text { integration of cultural texts in various forms: pictures, mind-maps, reading passages, and videos } \\
\text { relevant to the subject field, enables the students to interact indirectly with the cultures of } \\
\text { people from diverse communities. Answering questions and discussing language and cultural } \\
\text { elements as well as the contents of the texts shapes their critical thinking. Their achievement in } \\
\text { the role-play is the reflection of their improved ICC and shows their enhanced English skills. } \\
\text { Nevertheless, the students' limited grammatical knowledge and lack of writing practice became } \\
\text { constraints during their writing test. Further studies might investigate the solution for this } \\
\text { problem, especially related to the effectiveness of this intercultural teaching in other subject } \\
\text { areas. }\end{array}$} \\
\hline \multicolumn{2}{|c|}{ Keywords: Cultural texts; intercultural learning; intercultural communicative competence } \\
\hline $\begin{array}{c}\text { Revised: } \\
19 \text { February } 2021\end{array}$ & 31 May 2021 \\
\hline & \\
\hline
\end{tabular}

\section{INTRODUCTION}

There is a worldwide recognition that English has been spreading around the world at an increasing rate. This global language has certain varieties or "Englishes" depending on their locale and related circumstance of use (Joshi, 2011). Based on Kachru's (1985), there are three concentric circles of Englishes: native English in the inner circle, English as a second language in the outer circle, and English as a foreign language in the expanding circle. English in Indonesia belongs to the expanding circle. Even though it is not used as a second language, the use of English in various Indonesian sectors-education, business, and industry - has been supported by the government. The legal mandates can be seen, for example, in Article 33 Law 20/2003 and in Article 29 Law 24/2009.

However, English teaching in Indonesia mostly provide students limited access to practice their English, especially in the speaking and listening skills. In the last few decades, it has been one of the reasons for the less satisfactory EFL teaching in Indonesian schools and colleges (Kirkpatrick, 2007).

\footnotetext{
*Corresponding Author

Email: erna.andriyanti@uny.ac.id
} 
Other factors include class size and facility, students' motivation, lack of lecturers' competence, and teaching focus (Panggabean, 2015; Sulistiyo, 2016). Another concern is the importance of ICC in education due to the increasing opportunities for students to pursue higher degrees across nations (Murtiningsih, 2016). Among studies of intercultural competence in bilingual programs, a few have been conducted in Asian context, resulting in little information on how ICC is promoted to learners (Abduh \& Rosmaladewi, 2018).

In Indonesian context, many English lecturers have not integrated culture in their teaching materials (Abduh \& Rosmaladewi, 2018; Murtiningsih, 2016). Even though many teachers in Yogyakarta have high level of intercultural competence (Idris, 2020), results from a preliminary classroom observation and interview on students majoring in metallurgy engineering in one of the state universities in Yogyakarta showed that the students had few opportunities to practice English and they also did not have sufficient ICC to enhance their English learning. Consequently, they could not survive a good intercultural communication due to the absence of sufficient practice in their productive skills. They mostly spoke Bahasa Indonesia during their English lessons. Further, many of them were not aware of the importance of having intercultural awareness in global communication because their main goal of learning English was only to pass the final exam. Predictably, they were not able to sustain good communications and interactions in an intercultural setting. In fact, having a good communication skill can help EFL students communicate with other English speakers of different cultural backgrounds (Christie \& Listyani, 2018).

Incorporating cultural matters into EFL teaching has been highly suggested (Abduh \& Rosmaladewi, 2018; Ahnagari \& Zamanian, 2014; Baker, 2011; Kumari \& Nirban, 2018; Kusumaningputri \& Widodo, 2018; Liddicoat et al., 2003; Liu, 2016; Murtiningsih, 2016; Thao \& Tai, 2017; UNESCO, 2013). In higher education context, EFL lecturers need to have sufficient competencies in implementing intercultural teaching as it can foster not only students' communicative competence but also their intercultural communicative competence. Language students are also expected to master not only linguistic competence but also other kinds of competence to account for their language acquisition and language use (Canale, 1983; Canale \& Swain, 1980; Celce-Murcia, 2007; Celce-Murcia, et al., 1995; Madya, 2013). All of them are crucial to help learners understand the context and discourse of the target language. That is, they would be able to have better intercultural awareness which then lead them to achieve an ability commonly called as ICC.
Intercultural awareness is the cognitive aspect of intercultural communication and the understanding of one's own and others' culture that affect how people think and behave (Byram et. al., 2002; Liu, 2016). It is an essential prerequisite for developing ICC as it covers the knowledge of a foreign language learners necessarily have, as well as the skills and attitudes needed to communicate in English in diverse global contexts (Baker, 2011; Barany, 2016; Byram et al., 2002). The concept of ICC does not imply that someone has to wholly accept values of and behave exactly based on the target culture. Instead, someone who acts as an intercultural speaker should function appropriately in multicultural situations (Barany, 2016). That is to say, intercultural awareness is important for intercultural speakers to increase their international and cross-cultural understanding.

Therefore, in this research context, guiding students to develop their ICC through cultural texts was done with the aim of making them able to become intercultural speakers who enjoyed discovering and maintaining relationships with people from other cultural backgrounds, and respected others' values and did not believe theirs as the correct ones (Barany, 2016; Byram \& Fleming, 1998; Liddicoat \& Scarino, 2013; Nguyen, 2016). Several scholars (Bennet et al., 1999; Ennis, 2017; Liddicoat, 2011; Liddicoat \& Scarino, 2013; Madya, 2013) have suggested some models that English lecturers can use in their practice of intercultural teaching. Among the models, this research used the practice suggested by Madya (2013) as adapted from Liddicoat (2011) and Liddicoat and Scarino (2013), which consists of interaksi 'interacting', niteni 'recognizing through noticing several times', bandingkan 'comparing', refleksi 'reflecting', and simpulkan sementara 'concluding temporarily'. This model was chosen since it provides the evaluative result from reflection stage-simpulkan sementara "concluding temporarily'-that later leads learners to a continuous cycle of acquisition. Further, this research implemented Genre Approach (Feez, 1999) -which has a similar concept with Genre-based Approach by Richards (2006)- to teach the cultural texts as it is explicit, systematic, needsbased, supportive, empowering, critical, and consciousrising (Hyland, 2004).

Other instructional aspects such as the materials, activities, and types of assessment used in the intercultural teaching referred to Dai (2011), Liddicoat (2011), Liddicoat and Scarino (2013), and Skopinskaja (2009). Cultural texts related to the students' subject area were chosen as they can be the best ground for the genuine exploration of target culture and enhance students' critical thinking, autonomy and creativity (Chouhan, 2016; Larson \& Marsh, 2005; Tasneen, 2010; Van, 2009). In addition, role play was chosen since it provides a very useful rehearsal for real life and gives students 
a very wide variety of experience into the classroom (Brown, 2004).

This classroom action research was done to fill the gaps of the lack of intercultural teaching in the aforementioned Metallurgy Engineering Study Program. Several cultural texts relevant to the students' subject matter were those related to English as spoken by European and American communities because the Standard English usually taught in Indonesia is from the inner circle. Indonesian culture was used as comparison due to the participants' educational context. Creating an intercultural language teaching was expected to help the students improve ICC and provide space for them to use English actively. By having a good ICC, metallurgy engineering students are expected to be able to establish a communicative interaction by inferring the social meanings and responding to genuine communicative needs in their realistic language situations (see Aguilar, 2008). Particularly, this research answered the following questions: In what ways do cultural texts help students to understand culture differences? How can the teaching of English with an intercultural perspective be created using cultural texts? To what extent does intercultural teaching improve students' ICC?

\section{METHOD}

\section{Respondents}

The respondents were 22 first-year students and the English lecturer in class $\mathrm{K}$ of Metallurgy Engineering Study Program in a university in Yogyakarta, Indonesia in the first semester of the 2018/2019 Academic Year, from the beginning of October up to the middle of December.

\section{Instruments}

This research collected both qualitative and quantitative data. The qualitative data were obtained from classroom observations and interviews, while the quantitative data were gathered from spoken and written tests. During the classroom observation, an observation guideline was used to observe the teaching and learning process inside the classroom. Then, an interview guideline was used to administer interviews with the students before and after each cycle. Additionally, rubrics from the INCA project (Council of Europe, 2005), the Association of American Colleges and Universities (2009), and Brown (2001) were used during the written and spoken test. The rubric adapted from the INCA project (Council of Europe, 2005) was used to observe the students' intercultural knowledge in their writings during the written test. The adapted rubric from Association of American Colleges and Universities (2009) was used to observe the students' ICC during role play in the spoken test. Then, the adapted speaking rubric from Brown (2001) was chosen to measure the students' grammar, vocabulary, comprehension, fluency, and pronunciation during the role play. All of these data were documented using a camera and or an audio recorder.

\section{Procedure}

This three-cycle classroom action research was developed based on Kemmis and McTaggart (1988). Two researchers were involved, one of whom (the English lecturer's assistant) was allowed to become the "acting lecturer" who implemented the class actions. Meanwhile, the other researcher became the collaborator to conduct classroom observations and students' interviews. Before the class action, the researchers did a need analysis to modify the syllabus, prepare some materials, and decide contextual activities with the help of the lecturer. The qualitative data-related to contextual activities, detailed process of implementing the actions, and students' opinionwere obtained from classroom observations and interviews. Then, the quantitative data on students' performance were gathered from spoken test in the form of role play to assess students' behaviour and attitude, and written tests in the form of answering comprehension questions to assess students' intercultural knowledge (see also Liddicoat, 2011; Liddicoat \& Scarino, 2013; Skopinskaja, 2009).

\section{Data analysis}

The quantitative data were analyzed using descriptive statistics to see the mean scores on the students' writing, ICC, and speaking in each cycle. Meanwhile, the qualitative data were analyzed based on Miles et al. (2014) steps, consisting of data condensation, data display, and conclusions. To test the research validity, the researchers implemented the five types of validity: democratic validity, outcome validity, process validity, catalytic validity, and dialogic validity (Anderson et al., 2007). The trustworthiness of the data analysis was gained through time triangulation and investigator triangulation.

\section{FINDINGS}

Findings showed that the cultural-text based intercultural teaching implemented by following the steps of Genre Approach from Feez (1999) improved the students' intercultural awareness, ICC, and speaking skills. At first, the implemented treatment in cycle one successfully raised the students' intercultural knowledge and awareness. Nonetheless, almost all students showed a low level of ICC during the role play. Therefore, the researchers provided more exercises on the aspect of vocabulary, grammar, and pronunciation during cycle two. 
Based on the results of students' written test and role play in cycle two, the students started to show a better intercultural knowledge and ICC. Yet, they often mispronounced some English words and used minimal paralinguistic features. In this regard, activities in cycle three were designed to practice the students' pronunciation, grammar, English sentence structure, and paralinguistic competence. The research ended when the students showed improvements not only on their intercultural knowledge and ICC, but also on their speaking skills. Detail for this explanation could be seen on Table 1.

\section{Table 1}

The Overview of the Research Treatments from the Observation Guideline, Interview Guideline, and Rubrics Used

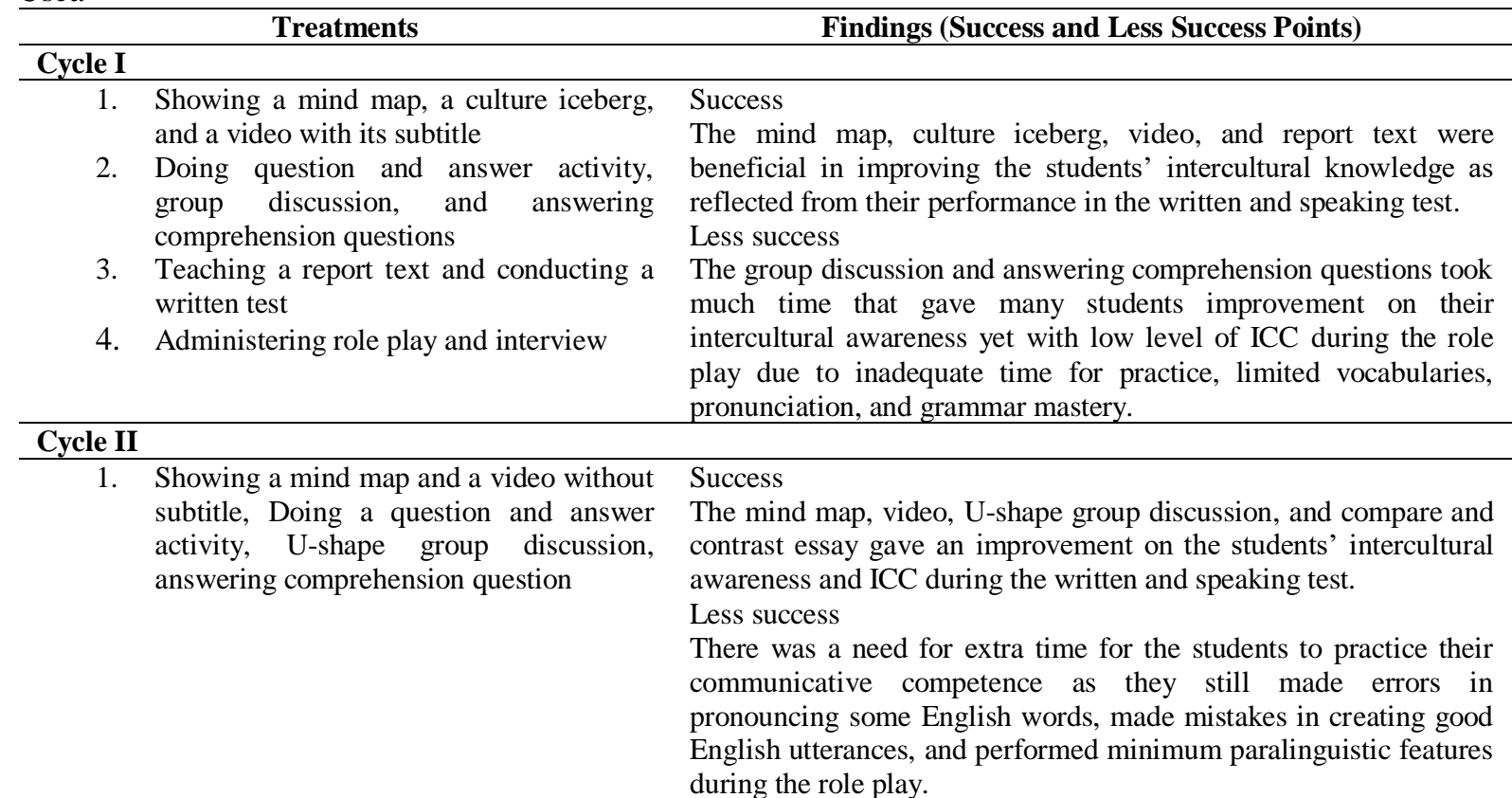

\begin{tabular}{ll}
\hline Cycle III \\
\hline 1. Showing pictures and a video about a \\
business meeting \\
2. Discussing the grammatical aspect and \\
paralinguistic features in the video being \\
played \\
3. Completing grammar exercises \\
4. Doing group discussion \\
5. Conducting role play and interview
\end{tabular}

\section{Success}

1. The pictures, video, group discussion and exercise on the grammatical aspect gave improvement on the students' intercultural awareness and ICC as shown in their written and speaking test results.

2. The discussion on the paralinguistic features in the video helped the students to pronounce the English words better and started to use paralinguistic features during their role play.

Less success

The written test seemed to make many students could not freely express their ideas since they see it as something difficult that hinder their creativity. Thus, they prefer role play as the media to interact with the cultures.

Examples of the students' statements during the interviews from Cycle one to Cycle three are the following.

I like it. It told me the condition of work safety culture in Indonesia. However, it's hard for me to understand when Miss Indah spoke in English. The role play was difficult too. (Student 1, Cycle 1)

The U-shape sitting arrangement made me less sleepy. The vocabulary list and sample of phrases used in business meeting helped me to create a better role play. But I am afraid of making mistakes in front of my friends. I also want to learn more about grammar and English sentence structure. (Student 2, Cycle 2)
The video helped me practice to be more expressive during the role play. I feel that I have a better speaking skill, especially for my vocabulary and grammar... and little bit of my pronunciation. I like role play as it allowed me to freely speak up my ideas. I don't really like writing. It feels too serious. (Student 3, Cycle 3)

The statements were supported by the research collaborator who said that this cultural text-based intercultural teaching was helpful to increase the students' intercultural awareness, ICC, and speaking skills. However, there is a need to give extra treatments to those who had negative attitude 
towards writing in English. Summary of their statements is following.

This intercultural teaching was helpful in improving the students' intercultural knowledge and ICC. They started to have better ICC... Yet, it was not easy to improve the students' motivation in writing, especially with our limited time. Maybe we could investigate this problem further next time." ( English lecturer, Cycle 3)

This conclusion was drawn from the changes of students' view when they were asked about the importance of knowing others' culture in language learning.

I guess it is important too. (Opinion of student 1 , Cycle 1)

Of course. Just like what we had discussed during the discussion session, international partnership is needed. (Opinion of student 2, Cycle 2)

Previously, I did not notice about it. Yet, now I know that it is very important as it can reduce misunderstanding. It also makes us notice more about our own culture. (Opinion of student 3, Cycle 3)

Results from the interviews also revealed that role play was an effective practice to improve the students' ICC. This improved competence was seen from the students' performances when they interacted with the target cultures during the role plays. Following are some of students' and lecturer's comments.

Role play really helps me to practice my speaking. I could perform as if I were someone else. (Student 4)
Through role play, I could practice to act as if I were in my real work field (Student 5)

Role plays do improve students speaking skills and intercultural communicative competence. The vocabulary lists, dialogues, and videos were also played as effective inputs. (English lecturer)

The data from classroom observation and interview aforementioned were strengthened by the results of students' written and speaking performances in all cycles.

Table 2 illustrates that from twenty-two students, the mean scores of the students' written test in all cycles are $1.14,1.68$, and 2.27 , with 1 categorized as low, 2 medium, and 3 high. This proved that the English intercultural teaching using cultural texts was effective in improving the students' intercultural knowledge in terms of comparing cultural facts with their own life experience and regroup different types of cultural characteristics. However, the improvements were not as significant as those in the speaking tests, as seen from the students' ICC scores during the role plays.

As displayed in Table 3, the mean scores of the students' ICC are 1.59, 2.1, and 2.57, with 1 categorized as low, 2 as lower-intermediate, 3 as upper-intermediate, and 4 as advance. Thus, the students' level of ICC started from low and increased to lower-intermediate in Cycle two, and reached almost upper-intermediate in Cycle three. In addition, there was also a significant improvement on the students' speaking skills (Table 4).

Table 2

The Descriptive Statistics of the Students' Writing Scores

\begin{tabular}{lccccc}
\hline & N & Minimum & Maximum & Mean & Std. Deviation \\
\hline Writing 1 & 22 & 1 & 2 & 1.14 & .351 \\
Writing 2 & 22 & 1 & 2 & 1.68 & .477 \\
Writing 3 & 22 & 2 & 3 & 2.27 & .456 \\
\hline
\end{tabular}

Table 3

The Descriptive Statistics of the Students' ICC Scores

\begin{tabular}{llllll}
\hline & $\mathrm{N}$ & Minimum & Maximum & Mean & Std. Deviation \\
\hline ICC 1 & 22 & 1.2 & 2.2 & 1.591 & .2860 \\
ICC 2 & 22 & 1.2 & 2.6 & 2.100 & .3638 \\
ICC 3 & 22 & 1.8 & 3.2 & 2.573 & .3820 \\
\hline
\end{tabular}

Table 4

The Descriptive Statistics of the Students' Speaking Skills Scores

\begin{tabular}{llllll}
\multicolumn{7}{l}{ The Descriptive Statistics of the Students } & Speaking Skills Scores & \\
\hline Speaking skill 1 & $\mathrm{N}$ & Minimum & Maximum & Mean & Std. Deviation \\
Speaking skill 2 & 22 & 2.4 & 3.4 & 2.727 & .2798 \\
Speaking skill 3 & 22 & 2.2 & 4.0 & 3.164 & .5038 \\
\hline
\end{tabular}

The students' speaking skills experienced a substantial improvement from cycle to cycle. In the test, their speaking skills were divided into five categories - 5 as very good, 4 as good, 3 as moderate, 2 as poor, and 1 as very poor. During
Cycle 1, the students' speaking skills did not reach the moderate level yet, and then started to increase to moderate in Cycle 2. Finally, the students' speaking skills improved to good in cycle 3 . 


\section{DISCUSSION}

This section is divided into three parts: the way cultural texts help students understand culture difference, the teaching process of English with an intercultural perspective using cultural texts, and the improvement on students' ICC through cultural textbased intercultural teaching.

\section{The way cultural texts help students understand culture difference}

Cultural texts involve objects, actions, and behaviours that reveal meanings (Malley \& Hawkins, 2018). The ones used in this research were pictures, mind-maps, reading passages (report and compare and contrast essays), and videos related to work safety and business cultures in the field of mining and metallurgy. Cultural texts enabled the students to have indirect interaction with the cultures of people coming from different communities (Larson \& Marsh, 2018). They also facilitated the students' exploration of the target culture by showing the rituals and rules of other cultures (Chouhan, 2016; Tasneen, 2010). On its implementation, the students were guided to read and analyze the similarities and differences between the cultures embedded in the texts. Then, through a group discussion, they shared their opinion related to the cultural aspects they have found. Further, several comprehension questions were provided to help them started the discussion. By reading and comparing the cultural aspects embedded in these texts, the students could enhance their critical thinking and intercultural awareness (Van, 2009).

From linguistic perspectives, these texts exposed the students with variety of styles, registers, and language teaching materials to practice their listening and reading skills. From methodological point of view, they helped the students to be open with various cultures. For motivational reasons, they stimulated the students to express their opinion about new cultural aspects they have never learnt before. However, the students' linguistic difficulty and different cultural knowledge became constraints during the teaching and learning processes. These problems were similar to those found by Tasneen (2010). Thus, the learning materials were adjusted with the students' English level and subject area.

The teaching process of English with an intercultural perspective using cultural texts

This cultural text-based intercultural teaching was implemented by following the steps of Genre Approach from Feez (1999). It taught the students not only the linguistic feature of English but also the cultural aspects of the text types they learned (Richards, 2006). During the stage of building the context, the students had an indirect interaction with the target cultures through the selected pictures, mind-maps, and videos relevant to their learning context. Then, they were guided to notice the new cultural aspects presented in the texts they learned through question and answer activities. In the stage of modelling and deconstructing the text, the students learned the generic structure and linguistic features of the texts being discussed. They also practiced several grammar exercises to enhance their understanding of the materials.

In the joint construction of the text stage, the teaching and learning processes were aimed at students' learning autonomy. Text labelling in pairs, comparing and contrasting their native and the new cultures they learned from the text through group discussion were done. Moreover, answering some reading comprehension questions was done individually and performing a role play based on the situation given. Finally, in the linking to related texts stage, the students were assisted to relate the text they learned to other text types through question and answer session. Further, they were asked their opinion regarding the intercultural learning they experienced through interview.

The implementation of English intercultural teaching gave positive impacts to the students. Even though at first they had low ICC during the role play, the implemented treatments during cycles two and three (see Table 1) could improve their intercultural awareness, ICC, and speaking skills. It proved that intercultural teaching could increase students' intercultural awareness and ICC (see also Abduh \& Rosmaladewi, 2018; Ahnagari \& Zamanian, 2014; Baker, 2011; Kumari \& Nirban, 2018; Kusumaningputri \& Widodo, 2017; Liddicoat et al., 2003; Liu, 2016; Murtiningsih, 2016; Thao \& Tai, 2017). It also matched with Council of Europe (2001, p. 43):

"The learner of a second or foreign language and culture does not cease to be competent in his or her mother tongue and the associated culture. Nor is the new competence kept entirely separate from the old. The learner does not simply acquire two distinct, unrelated ways of acting and communicating. The language learner becomes plurilingual and develops interculturality. The linguistic and cultural competences in respect of each language are modified by knowledge of the other and contribute to intercultural awareness, skills, and know-how."

Not only did this research broaden the students' cultural horizon, but it also succeeded in helping the students to move from the shell of their mother tongue and culture without changing their cultural identity (Ahnagari \& Zamanian, 2014; Madya, 2013). In addition, the improvements on the students' intercultural knowledge and speaking skills ascertained that Genre Approach was a useful approach to practice the students' English. Through this learning approach, the students could understand the cultural aspects as well as the linguistic features of different text types-report and compare and contrast essay-they learned. This links to Richards (2006) who mentioned that Genre- 
based Approach sees mastering different text types as part of communicative competence. The implemented Genre-based Approach is also in line with Feez (1999).

It taught the structures and grammatical features of the spoken and written texts explicitly. It linked the texts to the cultural context of their use, it designed units of works to develop the students' skills related to the texts, and it provided guided practices for students as they develop their language skills for meaningful communication through the texts. Furthermore, it was also explicit, systematic, needs-based, supportive, empowering, critical, and consciousness-raising (Hyland, 2004). It was explicit since it made clear what the students needed to learn. It was systematic as it gave a coherent framework to focus on both language and contexts that the students needed to master, and it was needsbased as the syllabus was designed based on a need analysis. Moreover, it was supportive since it provided the lecturer a central role in scaffolding the students' intercultural learning. It was empowering as it allowed variations in the texts used, and it was critical as it had challenges for the students to understand various cultures and point of views presented in the texts. Finally, it was conscious raising as it increased the students' and lecturer's knowledge and awareness of the cultural aspects in English-speaking countries.

Last but not least, the videos used during the research were also effective in enriching the students' intercultural knowledge and ICC. The videos helped them to see the various cultures in English communities and they gave real examples on the aspects of pronunciation and paralinguistic features. This finding underpinned that an audiovisual material is a great help for EFL students as they provide realistic models and various contact with speakers of the target language (Cakir, 2006; Harmer, 2001). It showed the students how people behave in the culture whose language they were learning, and it increased awareness of other cultures by allowing them to look at situation far beyond their classroom, creation, and motivation (Cakir, 2006; Harmer 2001).

\section{The improvement on students' ICC through cultural text-based intercultural teaching}

Findings from classroom observations, interviews as well as the students' speaking and written performances revealed that the use of cultural textbased intercultural teaching improved the students' level of intercultural knowledge and ICC. These findings strengthened the studies which stressed the importance of intercultural teaching to develop students' intercultural awareness and ICC (see Ahnagari \& Zamanian, 2014; Murtiningsih, 2016; Thao \& Tai, 2017). This research also corroborated several scholars (Liddicoat, 2011; Liddicoat \& Scarino, 2013; Skopinskaja, 2009) who avowed that role play and written test are useful technique for ICC assessment. It has also been well acknowledged that role play is indeed useful for practicing students' speaking skills as it provides a rehearsal for real life and gives students a very wide variety of experience into classroom (Brown, 2004).

Nonetheless, many students said that they were less interested in the written test despite attempts to engage them in the context of intercultural communication by focusing on the use of correct words in a correct context. Still the students struggled in their grammar and vocabulary due to lack of writing practice. This shows a common thread to the studies of Indonesian EFL teaching, most of which have found the low ability of students in writing English as they found it as stressful and difficult (Ariyanti, 2016; Hidayati, 2018; Sukandi, 2013). Thus, having good classroom management and knowledge of the students' preferred learning styles and strategies are essential for English lecturers (Brown, 2007).

Although role play succeeded in improving the students' communicative competence, English lecturers need to consider aspects related to time and students' condition in which they might feel shy or afraid of making mistakes during the role-play (Kucuker, 2004). Henceforth, lecturers have to be able to switch between various roles according to the situation of their students. Then, they have to be aware of how they carry out and perform those roles - whether they want to be facilitator, observer, prompter, or other roles (Harmer, 2001).

Additionally, this research gives new insight into the practice of intercultural teaching for EFL students in Indonesian university level. Unlike other studies (Abduh \& Rosmaladewi, 2018; Ahnagari \& Zamanian, 2014; Kumari \& Nirban, 2018; Kusumaningputri \& Widodo, 2017; Murtiningsih, 2016; Thao \& Tai, 2018) which mostly focused on stressing the importance of raising students' ICC in EFL classroom, it provides an example on the practice of teaching. It shows readers how to implement the English intercultural teaching, types of cultural texts used and their significance for the students' understanding of culture difference, and some constraints appeared during the teaching and learning processes.

\section{CONCLUSION}

This present study provides evidence that cultural text-based intercultural teaching was successful in developing students' intercultural awareness and ICC. It could be seen from the results of class observation, the students' and lecturer's interviews, and the students' speaking and written tests. The integration of cultural texts in various forms: pictures, mind-maps, reading passages, and videos helps the students to interact indirectly with people from diverse cultures and communities. Answering 
questions and discussing language and cultural elements and the contents of the texts shape their critical thinking. Their achievement in the role-play reflects their improved ICC and shows their enhanced English skills.

The research findings have essential implications for the teaching and learning process of English in the expanding circle. Yet, it used indirect interactions with the target cultures and many students still had low motivation to write in English when the research ended. Thus, further studies are suggested to provide direct interaction towards the target culture, and investigate the solution for students' negative attitude toward writing in English, and evaluate the effectiveness of this intercultural teaching in other subject areas.

\section{REFERENCES}

Abduh, A., \& Rosmaladewi, R. (2018). Promoting intercultural competence in bilingual programs in Indonesia. Sage Open, 8(3), 1-7. https://doi.org/10.1177/2158244018788616

Aguilar, M. J. C. (2008). Dealing with intercultural communicative competence in the foreign language classroom. In E. A. Soler, \& P. S. Jordà (Eds.). Intercultural language use and language learning (pp. 59-78). Springer.

Ahnagari, S., \& Zamanian, J. (2014). Intercultural communicative competence in foreign language classroom. International Journal of Academic Research in Business and Social Sciences, 4(11), 9-16. https://doi.org/10.6007/IJARBSS/v4-i11/1265

Anderson, G. L., Herr, K., \& Nihlen, A. S. (Eds.). (2007). Studying your own school: An educator's guide to practitioner action research. Corwin Press.

Ariyanti, A. (2016). The teaching of EFL writing in Indonesia. Dinamika Ilmu, 16(2), 263-277. https://doi.org/10.21093/di.v16i2.274

Association of American Colleges and Universities. (2009). Intercultural knowledge and competence value rubric. Retrieved from https://www.aacu.org/value/rubrics/inquiryanalysis.

Baker, W. (2011). Intercultural awareness: Modelling an understanding of cultures in intercultural communication through English as a lingua franca. Language and Intercultural Communication, 11(3), 197-214. https://doi.org/10.1080/14708477.2011.577779

Barany, L. K. (2016). Language awareness, intercultural awareness and communicative language teaching: Towards language education. International Journal of Humanities and Cultural Studies, 2(4), 257-275. https://www.ijhcs.com/index.php/ijhcs/article/ view/183
Bennet, J. M., Bennet, M. J., \& Allen, W. (1999). Developing intercultural competence in the language classroom. In R. M. Paige, D. L. Lange, \& Y. A. Yershova (Eds). Culture as the core: Integrating culture into the language curriculum (pp. 13-46). University of Minnesota.

Brown, H. D. (2001). Teaching by principles: An interactive approach to language pedagogy. (2nd ed.). Pearson Education.

Brown, H. D. (2004). Language assessment: Principles and classroom practices. Pearson Education.

Brown, H. D. (2007). Principles of language learning and teaching. Pearson Education.

Byram, M. \& Fleming, M. (1998). Language learning in intercultural perspective: Approaches through drama and ethnography. Cambridge University Press.

Byram, M., Gribkova, B. \& Starkey, H. (2002). Developing the intercultural dimension in language teaching: A practical introduction for teachers. Council of Europe.

Cakir, I. (2006). The use of video as an audiovisual material in foreign language teaching classroom. The Turkish Online Journal of Educational Technology-TOJET, 5(4), 67-72. http://www.tojet.net/articles/v5i4/549.pdf

Canale, M. (1983). From communicative competence to communicative language pedagogy. In J. C. Richards \& R. W. Schmidt (Eds.). Language and Communications. (pp. 227). Longman.

Canale, M., \& Swain, M. (1980). Theoretical bases of communicative approaches to second language teaching and testing. Applied Linguistics, 1(1), 1-47. https://doi.org/10.1093/applin/I.1.1

Celce-Murcia, M. (2007). Rethinking the role of communicative competence in language teaching. In E. A. Soler \& M. P. S. Jordà (Eds.), Intercultural language use and language learning (pp. 41-57). https://doi.org/10.1007/978-1-4020-5639-0_3

Celce-Murcia, M., Dörnyei, Z., \& Thurrell, S. (1995). Communicative competence: A pedagogically motivated model with content specifications. Issues in Applied Linguistics, 6(2), 5-35. https://escholarship.org/uc/item/2928w4zj

Christie, L.S. \& Listyani (2018). Teachers' strategies to improve students' self-confidence in speaking: A study at two vocational schools in Central Borneo. Register Journal, 11(2), 139. https://doi.org/10.18326/rgt.v11i2.139153

Chouhan, A. (2016). Teaching English language through literature: A critical study. International Journal of English Language, Literature and Humanities, IV(VIII), 266-271. 
https://ijellh.com/OJS/index.php/OJS/article/vi ew/1588

Council of Europe. Council for Cultural Cooperation. Education Committee. Modern Languages Division. (2001). Common European framework of reference for languages: Learning, teaching, assessment. Cambridge University Press.

Council of Europe. Education and Culture. (2005). Portfolio of intercultural competence, INCA Project, Leonardo da Vinci program: European training for the UK. https://ec.europa.eu/migrantintegration/librarydoc/the-inca-projectintercultural-competence-assessment

Dai, L. (2011). Practical techniques for culturalbased language teaching in the EFL classroom. Journal of Language Teaching \& Research, 2(5), 1031-1036. http://www.academypublication.com/issues/pa st/jltr/vol02/05/11.pdf

Ennis, M. J. (2017). Integrating intercultural learning in English for specific academic purposes. In M. J. Ennis \& C. E. Riley (Eds.), Practices in intercultural language teaching and learning (pp. 145-168). Cambridge Scholars.

Feez, S. (1999). Text-based syllabus design. TESOL in Context, 9(1), 11-14. https://search.informit.org/doi/pdf/10.3316/iela pa.661538732574164

Harmer, J. (2001). The practice of English language teaching. Longman.

Hidayati, K. H. (2018). Teaching writing to EFL learners: An investigation of challenges confronted by Indonesian teachers. Langkawi: Journal of The Association for Arabic and English, 4(1), 21-31. http://dx.doi.org/10.31332/lkw.v4i1.772

Hyland, K. (2004). Second language writing. Cambridge University Press.

Hymes, D. (1972). On communicative competence. In J. Pride \& J. Holmes (Eds.). Sociolinguistics. Penguin Books.

Idris, M. M. (2020). Assessing intercultural competence (IC) of state junior high school English teachers in Yogyakarta. Indonesian Journal of Applied Linguistics, 9(3), 628636. https://doi.org/10.17509/ijal.v9i3.23213

Joshi, P. (2011). ENL, ESL, and EFL: The quest for a paradigmatic model. ELT Voices, 1(1).

Kachru, B. B. (1985). Standards, codification and sociolinguistic realism: The English language in the outer circle. In R. Quirk, \& H. G. Widdowson. (Eds.), English in the world: Teaching and learning the language and literatures (pp. 11-30). Cambridge University Press.

Kemmis, S. \& McTaggart, R. (1988). The action research planner. Deakin University Press.
Kirkpatrick, A. (2007). Teaching English across cultures: What do English language teachers need to know to know how to teach English. English Australia Journal, 23(2), 20-36. https://core.ac.uk/download/pdf/143879198.pd $\mathrm{f}$

Kucuker, Y. (2004). The effects of activities based on role-play on ninth grade students, achievement and attitudes towards simple electric circuits. Retrieved on March 2, 2019, from https://etd.lib.metu.edu.tr/upload/12605375/ind ex.pdf

Kumari, P., \& Nirban, V. S. (2018). Intercultural communication competencies in the Indian Information Technology industry.

International Journal of Cross-Cultural Management, 18(3), 327-347. https://doi.org/10.1177/1470595818812996.

Kusumaningputri, R., \& Widodo, H. P. (2018). Promoting Indonesian university students' critical intercultural awareness in tertiary EAL classrooms: The use of digital photographmediated intercultural tasks. System, 72, 4961. https://doi.org/10.1016/j.system.2017.10.003

Larson, J., \& Marsh, J. (2005). Making literacy real: Theories and practices for learning and teaching. Sage Publications.

Liddicoat, A. J. (2011). Language teaching and learning from an intercultural perspective. In E. Hinkel (Ed.). Handbook of research in second language teaching and learning (Vol. 2, pp. 837-855). Routledge.

Liddicoat, A.J, \& Scarino, A. (2013). Intercultural language teaching and learning. WileyBlackwell.

Liddicoat, A. J., Scarino, A., Papademetre, L., \& Kohler, M. (2003). Report on intercultural language learning. Commonwealth Department of Education, Science and Training.

Liu, C. (2016). Cultivation of intercultural awareness in EFL teaching. Journal of Language Teaching and Research, 7(1), 226232. https://doi.org/10.17507/jltr.0701.26

Madya, S. (2013). Metodologi pengajaran bahasa dari era prametode sampai era pascametode. UNY Press.

Malley, S., \& Hawkins, A. (2018). Examining culture as text. Retrieved from www.engagingcommunities.org/proposing-theethnographic-researchproject/3a-examiningculture-as-text/

Miles, M. B., Huberman, A. M., \& Saldaña, J. (2014). Qualitative data analysis: A methods sourcebook (3rd ed.). SAGE Publications.

Murtiningsih, B. S. E. (2016). The role of cultural competence to overcome intercultural communication conflict: Case study of 
Indonesian and Korean students in Kyungsung University, South Korea. Mediterranean Journal of Social Sciences, 7(6), 213-222. https://doi.org/10.5901/mjss.2016.v7n6p213

Nguyen, T. T. T. (2017). Integrating culture into language teaching and learning: Student outcomes. The Reading Matrix: An International Journal, 17(1), 145- 155. https://readingmatrix.com/files/16lm7civ98.pdf

Panggabean, H. (2015). Problematic approach to English learning and teaching: A case in Indonesia. English Language Teaching, 8(3). https://doi.org/10.5539/elt.v8n3p35

Richards, J. C. 2006. Communicative language teaching today. Cambridge University Press.

Skopinskaja, L. (2009). Assessing intercultural communicative competence: Test construction issues. Synergies Pays Riverains de la Baltique, 6(2009), 135-144. https://gerflint.fr/Base/Baltique6/liljana.pdf

Sukandi, S. S. (2013). Teaching writing to Indonesian EFL learners: Challenges of the "voice" and "style" in adjusting cross cultural communication skills. In Proceedings International Seminar: Language Teaching in
Cross Cultural Communication Context (pp. 136-147).

Sulistiyo, U. (2016). English language teaching and EFL teacher competence Indonesia. ISELT4(pp. 396-406). http://ejournal.unp.ac.id/index.php/selt/article/ view/7001

Tasneen, W. (2010). Literary texts in the language classroom: A study of teachers and students views at International school in Bangkok. Asian EFL Journal, 12(4), 173-187. http://asian-efl-journal.com/PDF/Volume-12Issue-4-Tasneen.pdf

Tran, T. Q., \& Tai, P. T. (2017). The importance of intercultural communicative competence in English language teaching and learning. Proceeding of Open TESOL (pp. 629-641). Ho Chi Minh Open University.

UNESCO. (2013). Intercultural competences. UNESCO.

Van, T. T. M. (2009). The relevance of literacy analysis to teaching literature in EFL classroom. English Teaching Forum, 47(3), 29. https://files.eric.ed.gov/fulltext/EJ923454.pdf

\section{APPENDIX \\ Example of teaching material}

\section{Indonesian and German Business Culture: Are they similar?}

Technology has made doing business worldwide much easier, and for many companies the recession of recent years has made a global outlook a necessity. Yet, even though taking on global partners or expanding into emerging markets offers many opportunities; it also brings challenges, not the least of which is the cultural differences that arise when doing business with other countries. One of the examples is the business between Indonesia and Germany. As a country with the largest economy in Europe, Germany is one of the potential countries for Indonesia to work with. However, a good deal of business will not happen unless both countries understand each other. That is why, we will be looking at the business culture between Indonesia and Germany in order to foster our effective communication as it is a vital aspect for successful business. Specifically, we will look more on things that equalize and differentiate these two.

The first discussion is about Indonesian business culture. In Indonesian, hierarchy plays a big role. Thus, greetings can be rather formal as they are meant to show respect. A handshake completed with using titles in conjunction with the name is a common for Indonesians. However, many Indonesian people are indirect communicators who speak quietly and with a subdued tone. They abhor confrontation due to the potential loss of face. To be polite, they may tell you what they think you want to hear. So, listeners need to read between the lines or pay attention to gestures and body language to get the real message. Moreover, business in Indonesia is personal - it is important to spend time through communication to build a strong relationship. As a result, initial meetings may be more about getting-to-know-you rather than business. Jam Karet (rubber time) is commonly used to describe the Indonesians approach to time. Things are not rushed as the attitude is that everything has its time and place. This is because time does not bring money, good relations and harmony do. Furthermore, it is also common for Indonesians to not make hasty decisions because they might be viewed as not having given the matter sufficient consideration. If negotiating, avoid pressure tactics as they are likely to backfire. Therefore, be prepared to exercise patience.

Similarly, hierarchy is one of the essential values in German business culture. The way they do greetings is also the same as Indonesians. However, unlike Indonesian business culture which is personal, Germany has 
better punctuality, directness and a certain measure of separation between work and private life. That is, make sure that you arrive on time and ready to start. Being early could be considered as much of a misstep as being late, as it shows poor planning, so do not arrive more than a few minutes before the scheduled time. Moreover, Germans like to analyse and review information in detail before coming to a decision. Thus, you need to be patient and do not try to rush people to make a decision. Also, avoid surprising German colleagues with unexpected information or a change in direction, as it can push them away.

Savvy businesses of all sizes are realizing the necessity of breaking into the global marketplace. If your company plans to expand into international markets or use global partners, it's vital that the key participants understand and appreciate the culture of the people with whom they'll be doing business.

Questions:

1. What is the main idea of the text?

2. Would you identify the similarities between the business culture in Indonesia and in Germany? What are they?

3. Would you identify the differences between the business culture in Indonesia and in Germany? What are they?

4. What cultural aspects of business culture that you can get from the text?

5. In your opinion, is it important for us (if we want to do international business) to understand a country's business culture? Why so? 